\title{
既存低層鉄筋コンクリート造建物における構造耐震指標 (Is 值) と被災度の関係 一地震応答解析による検討一 \\ ASSESSMENT OF DAMAGE LEVEL FOR EXISTING LOW-RISE RC BUILDINGS BASED ON SEISMIC CAPACITY INDEX (Is) \\ - Study by dynamic analysis-
}

\author{
芳村 学*，中村孝也**，八木克已*** \\ Manabu YOSHIMURA, Takaya NAKAMURA and Katsumi YAGI
}

\begin{abstract}
Seismic performance of existing RC buildings is evaluated by computing seismic capacity index, Is, using the Standard for Seismic Evaluation of Existing RC buildings, while damage level of RC buildings that undergo earthquakes is assessed by the Standard for Post-Earthquake Inspection and Guidelines for Repair and Strengthening. This research is intended to study Is vs. damage level relations for low-rise RC buildings designed by the old code by conducting dynamic analysis on model buildings with a variety of Is values. The effects of deformability type of columns and number of stories on the relations are studied. Two levels of ground motions, the original level of past earthquake records and design standard level, are considered. In the analysis, column hysteresis is derived from test results. Strength deterioration after shear failure and axial collapse that are commonly associated with hysteretic behavior of old columns, are considered. The method presented in this study enables us to assess the damage level of buildings and the damage conditions of the columns if the deformability type of columns, number of stories, Is value and ground motion are given. In addition, the assessed damage level of buildings is compared with the observed damage level from past earthquakes and the Is value required to prevent collapse of buildings is discussed.
\end{abstract}

Keywords: Reinforced concrete building, Seismic capacity index, Damage level, Dynamic analysis 鉄筋コンクリート造建物, 構造耐震指標, 被災度, 地震応答解析

\section{1. はじめに}

既存鉄筋コンクリート（RC）造建物の酎震性能を評価する一般的 手法である耐震診断基淮 1)では、構造耐震指標 Is 值が計算され、そ の大小に応じて建物の耐震性が評価される。

一方、地震被害を受けた建物の被災度は、被災度区分判定 ${ }^{2), 3) に よ ~}$ り評価されるのが一般的である。兵庫県南部地震における被災度区 分判定は文献 2)の方法によっている。その 1 例として、学校建築枌 行方向における耐震 2 次診断による Is 值と損賃指標 $\mathrm{D}$ の関係を図 1 に示す 1)。この図から、Is 值が大きくなるにしたがい D が減少する 傾向が明暸であるが、同時に、同じ Is 值でも D には大きなばらつき があることもわかる。この理由として、1) 同じ地震といっても個々 の建物に作用した地震動レベルが違っていた、2) 同じ Is 值といっ ても個々の建物の柱種別により応答性状が異なっていた、3) 同じ Is 值といっても建物階数により固有周期が異なっていた、ことなどが 考えられる。

このように、Is 值と被災度の関係についてはいまだ不明な点が存
在するのであるが、それを明らかにするためには、個別の建物被災 事例を対象とした検討たとえば 4),5)ではその数が限られているため十分 ではなく、モデ建物による組織的な検討を行うことが必要である。

そこで本研究では、旧基準による低層 RC 造モテル建物を対象と して、Is 值をパラメーターとした地震応答解析を行い、Is 值と被災 度レベルの関倸付けを行うことを試みる。モデル建物では柱種別と 建物階数の違いを考慮する。また、地震動レベルとして、観測され た地震動の原記録およびその最大速度を $50 \mathrm{~cm} / \mathrm{s}$ に基準化した 2 種類 を考慮し、前者に対しては主に過去の地震における被災度と本検討 結果との対応を、後者に対しては主に耐震設計時によく考慮される レベルの地震動に対する Is 值と被災度の関係、特に倒壊を免れるた めに必要な Is 值について、検討する。その際、実験結果に基づき柱 の復元力特性と変形一損傷度関係を決める。ここで、古い RC 造建 物では柱のせん断破壊後の急激な耐力低下および軸力保持能力嵔失 の扱いが重要であるため、本論ではそれらを考虑し、倒壊を柱の軸 力保持能力彗失と関連づけて定義する。

\footnotetext{
* 東京都立大学大学院工学研究科建築学尃攻 教授. 工博

** 東京都立大学大学院工学研究科建築学専攻 助手・修士(工学)

****陎東芝 修士(工学)
}

Prof., Department of Architecture, Graduate School of Engineering, Tokyo Metropolitan Univ., Dr. Eng.

Research Assoc., Department of Architecture, Graduate School of Engineering, Tokyo Metropolitan Univ., M: Eng.

Toshiba, M. Eng. 


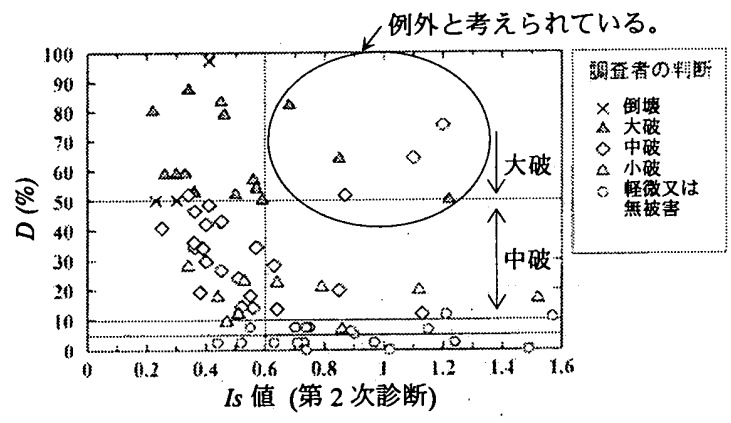

図 1 学校建築における Is 值-D関係 (桁行方向、兵庫県南部地霞) 1 ), 182 面

\section{2. 解析方法}

\section{1 解析モデル概要}

解析モデルを図 2 に示す。 71 年以前に建設された旧基準 RC 造 3 層、5 層建物を解析対象とし、これらを各層 2 種類の柱からなるせ ん断型モデに置換した。各層階高を $360 \mathrm{~cm}$ 、各層重量を $753 \mathrm{kN}$ と 仮定した。解析方向として建物の柧行方向を想定し、その方向には 耐震壁がないものとした。

解析モテルの概要を以下に示す。

(1) 図 3 に示すような建物をイメージし、2 種類の柱からなる 3 種 類のモデを設定した。極脆性柱（柱内法高さ $h_{0}=120 \mathrm{~cm}$ 、柱せい $\left.\mathrm{D}=60 \mathrm{~cm} 、 \mathrm{~h}_{0} / \mathrm{D}=2\right)$ とせん断柱（ $\mathrm{h}_{0}=240 \mathrm{~cm} 、 \mathrm{D}=60 \mathrm{~cm} 、 \mathrm{~h}_{0} / \mathrm{D}=4 ）$ から なる建物をモデル 1、極脆性柱と診断基準ではせん断型と判定され るが実際には曲げ降伏する柱（曲げ柱と称し詳しくは(3)で記す、 $\left.\mathrm{h}_{0}=240 \mathrm{~cm} 、 \mathrm{D}=60 \mathrm{~cm} 、 \mathrm{~h}_{0} / \mathrm{D}=4\right)$ からなる建物をモテル 2、せん断柱と 曲げ柱からなる建物をモテル 3 とした。各柱は過去の実験の,クで用い た試験体の 2 倍のサイズとした。実験については 2.2 節で述べるが、 極脆性柱、せん断柱、曲け柱として、各々文献 6)の 2C、文献 7)の No.1、No.8 試験体を用いた。

（2）建物高さ方向の強度分布は、一般的な旧基準建物を想定して長 方形分布外力から定めた。ただし、上部 2、3 首程度は柱を細くしな いのが一般的であることから、上部 3 首は同一強度とした。そのた め、 3 首建物ではすべての層が同一強度となり、 5 層建物では 3 層以 上が同一強度となった（図 4)。

建物に極脆性柱が含まれる場合、それらが負担する強度の割合を 全体の 3 割と仮定し、モデル 1 では各首における極脆性柱とせん断 柱の最大強度の比を 3 対 7 とし、モデル 2 でも極脆性柱と曲げ柱の 最大強度の比を 3 対 7 とした。モテル 3 ではせん断柱と曲げ柱の最 大強度の比を 1 対 1 とした。これらの比は各層について同一とした。 (3) 各モデル Is 值を耐震 2 次診断により算定した。Is 值をパラメ 一ターとするときに、各部材の勒性指標 $\mathrm{F}$ は一定とし、強度指標 $\mathrm{C}$ のみを変えて Is 值を変化させた。本研究では、形状指標 $\mathrm{S}_{\mathrm{D}}$ と経年 指䟱 Tは 1.0 とした。

試験体の寸法を 2 倍にして計算した各柱の勒性指標 $\mathrm{F}$ は、極脆性 柱では $\mathrm{F}=0.8$ 、せん断柱では $\mathrm{F}=1.0$ 、曲げ柱では $\mathrm{F}=1.10$ であった。 計算にあたって、各柱の軸力比は実験時と同じにした (2.2 節参照)。 ここで、曲げ柱は、実験では曲け降伏したのであるが、耐震診断に おいてはせん断型と判定されたため（診断基準で定められている荒 川 $\mathrm{min}$ 式によるとせん断余裕度は 0.95)、計算上はせん断型として F を算定した。なお、この柱について、せん断強度式として荒川 mean
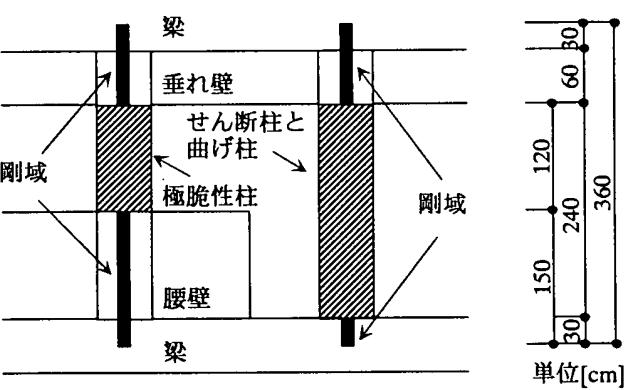

図 3 実建物のイメージ

式を用いると曲け型となるが、その場合でも $\mathrm{F}=1.13$ で、前記との違 いはほんのわずかである。各柱の勒性指標 $\mathrm{F}$ は全首同一とした。

2.4 節で述べるように、本論では軸力保持限界を別途考慮している ので、診断基準の適用にあたっても第 2 種構造要素による制限は設 けなかった（この点で診断基準と異なることに注意を要する）。モ テル 1、2 の Is 值は、文献 1)の 83 頁に記されているように、極脆性 柱が破壊する時点での診断基淮(5)式と極脆性柱を無視した診断基 準(4)式で検討した結果、後者で決まった。また、モデル 3 の Is 值は、 せん断柱が破壊する時点での診断基準(5)式で決まった。

設定した強度分布により、3 層建物では 1 首の Is 值が、 5 層建物 では 3 層の Is 值が最も低い值となり、これを建物の Is 值とした。図 5 に建物の Is $=0.4$ のときの各層の Is 值分布を示す。

（4）建物高さ方向の初期剛性分布は強度分布と同じにした。また、 建物の初期剛性は Is 值にしたがい変化するものとした。

旧基準建物が保有する耐震性能としては、Is=0.4 程度が統計的に 多い ${ }^{8)}$ ため、Is=0.4 のときの 1 次固有周期を 3 層建物で 0.22 秒（建 物高さ $[\mathrm{m}] \times 0.02$ )、 5 㕌建物で 0.36 秒（同左）となるように初期剛性 を決定し、これを基準とした。その他の Is 值を持つ建物では、Is 值 に比例させ初期剛性を定めた。すなわち、ある Is 值から 2 倍の Is 值になったとき、初期剛性も 2 倍になるものとした。図 6 に Is 值と 1 次固有周期の関係を示す。

各柱に分担させる初期剛性の比は.2.3 節で述べる復元力特性から 定まる最大強度時の点と原点を結ぶ剛性の比とした。

表 1 に各モテルにおける 2 本の柱の強度と初期剛性の分担割合を 示す。上記の方法で柱の初期剛性を定めた場合、モテル 1 とモテル 2 において極脆性柱の初期剛性分担割合が強度分担割合より大きく なるが、後述のように、本研究の復元力モデルでは初期剛性を変え てもひび割れ点が変化するだけであるので、初期剛性の仮定の影響 は小さい9。

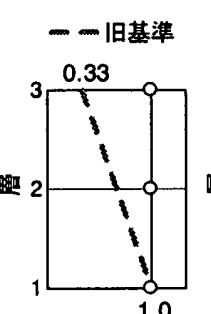

強度

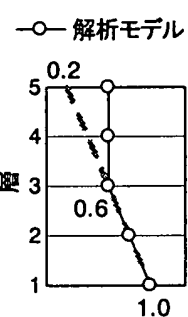

強度

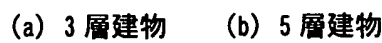

図 4 強度分布

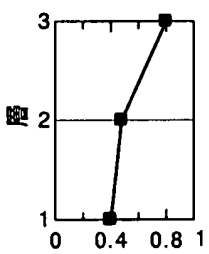

Is值

(a) 3 層建物

图 5 |s 值分布 (建物の $\mid s=0.4)$ 


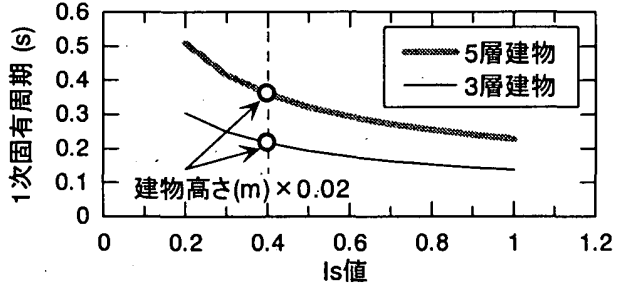

图 6 Is 值と 1 次固有周期の関係

表 1 柱の強度と初期剛性の分担割合

\begin{tabular}{c|c|c|c}
\hline モテル & 柱種類 & 強度比 & 初期剛性比 \\
\hline \multirow{2}{*}{ モデル 1} & 極脆性柱 & $30 \%$ & $59 \%$ \\
\cline { 2 - 4 } & せん断柱 & $70 \%$ & $41 \%$ \\
\hline \multirow{2}{*}{ モデル 2} & 極脆性柱 & $30 \%$ & $59 \%$ \\
\cline { 2 - 4 } & 曲げ柱 & $70 \%$ & $41 \%$ \\
\hline \multirow{2}{*}{ モデル 3} & せん断柱 & $50 \%$ & $50 \%$ \\
\cline { 2 - 4 } & 曲げ柱 & $50 \%$ & $50 \%$ \\
\hline
\end{tabular}

\section{$2.2 \mathrm{RC}$ 柱の実験}

極脆性柱、せん断柱、曲げ柱（各々2C、No.1、No.8）に対応する $\mathrm{h}_{0} / \mathrm{D}=2$ と $\mathrm{h}_{0} / \mathrm{D}=4$ の試験体は、軸力比 0.2 （2C のみ 0.19）のもとで繰 り返し載荷を行い、軸力を保持し得なくなる変形まで加力したもの である。すべての試験体が、軸力保持限界を越えた途端、それまで 支えていた軸力を保持できなくなり鈶直方向に崩嬙した。図 7 に水 平力と部材角、首間変形角の関倸を、写真 1 に各変形時に得られた 写真を示す。部材角と層間変形角の関係は図 3 に示した建物イメー ジに基づいて、階高 $360 \mathrm{~cm}$ を考慮して算定した（以下、この節と 2.3 節での部材角の後の括弧内は層間変形角を表す)。

極脆性柱はせん断破壊した。部材角 $0.27 \%$ （0.09\%）のときに最大 強度に達し、部材角 $7.8 \%$ （2.6\%）のときに軸力保持限界に達した。 せん断柱もせん断破壊した。部材角 $1.0 \%$ （0.67\%）のときに最大強 度に達し、部材角 $13.4 \%$ （8.93\%）のときに軸力保持限界に達した。

\section{最大強度時 (実験) \\ 軸力保持限界(実験) \\ $\diamond$ 最大強度時(解析) \\ ○ 軸力保持限界 (解析) \\ 部材角 $(\%)$}

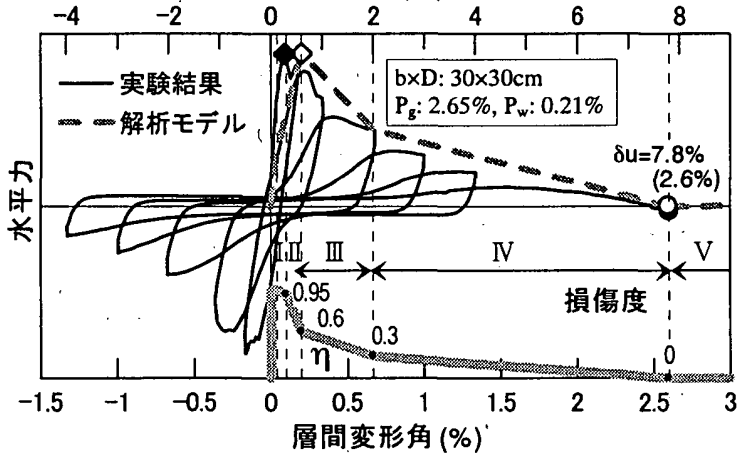

部材角
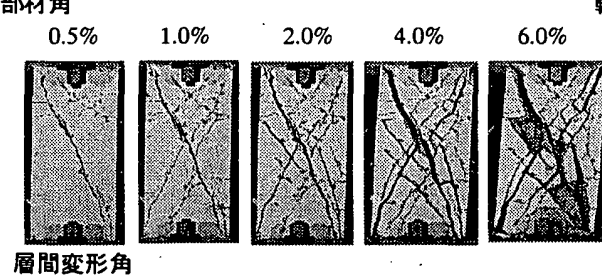

朝力保持限界 軸力保持限界後

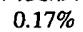

損僨度 |
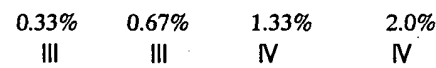

（a）極脆性柱

(a) 極脆性柱

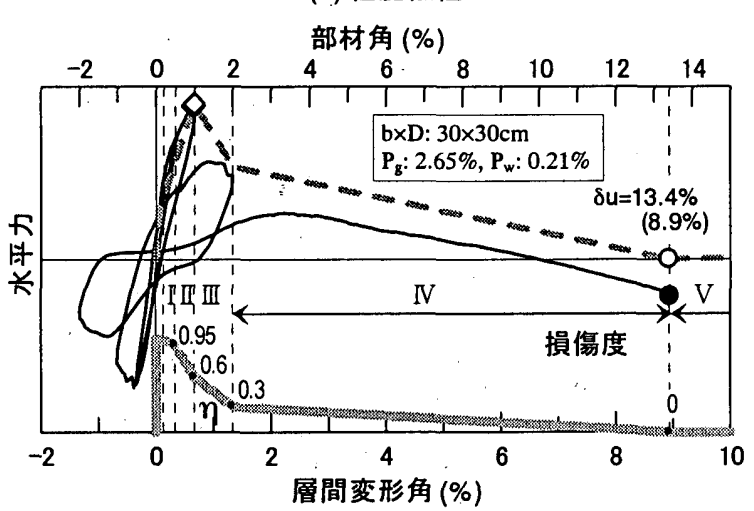

(b) せん断柱

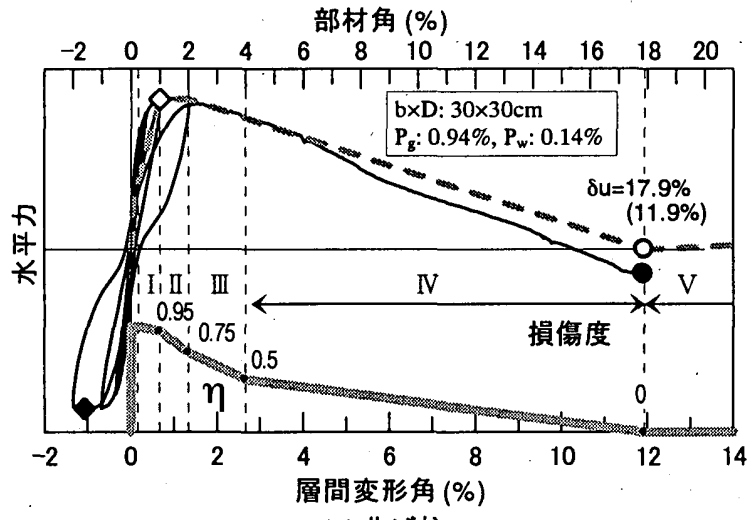

(c) 曲げ柱

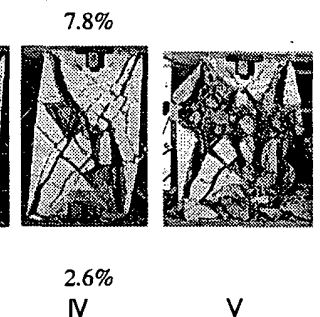

部材角

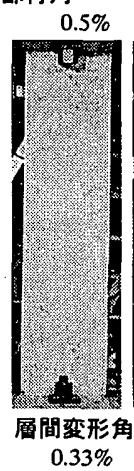

損偒度

部材角

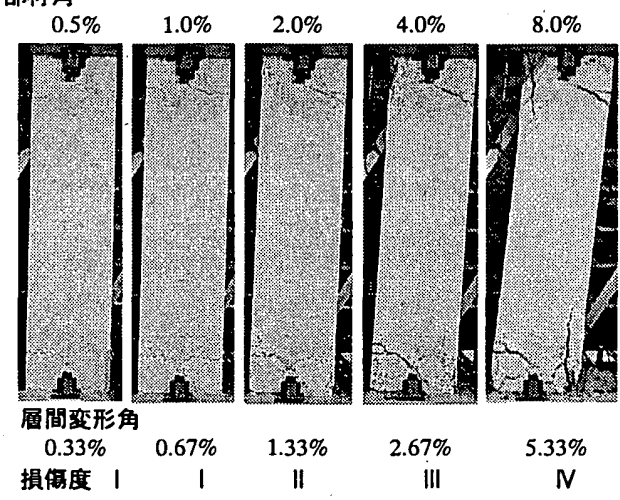

(c) 曲げ柱
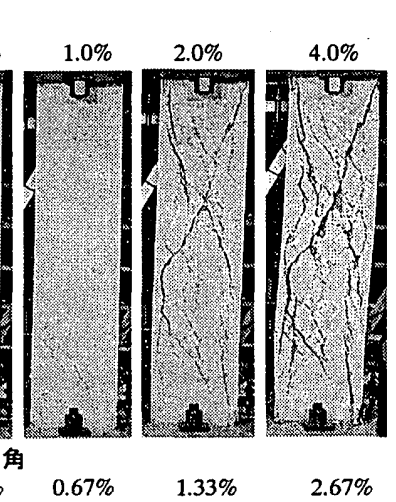

V

せん断柱

$33 \%$

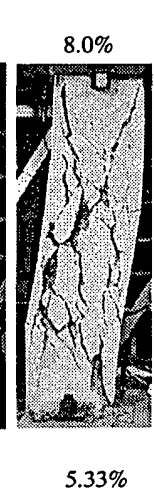

軸力保持限界 軸力保持限界後 $17.9 \%$

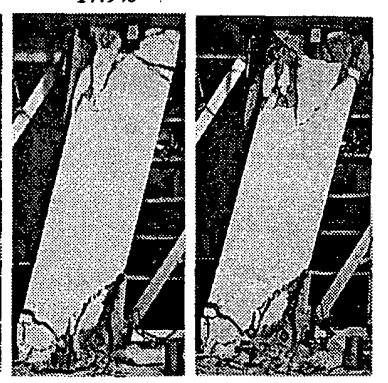

$11.9 \%$

N

図 7 実験結果、解析で使用する復元力のスケルトン、損傷度と $\eta$

写真 1 試験体の破壊状況 
他方、曲け柱は曲け降伏した。部材角-1.6\%（-1.1\%）のときに最大 強度に達し、部材角 $17.9 \%$ (11.9\%)のときに軸力保持限界に達した。 この柱は計算上せん断型と判定されたが、実際には曲け降伏し、優 れた変形能を示した。なお、図 7 に示した損賃度と $n$ については 2.4 節で述べる。

\section{3 復元力特性モテル}

解析における復元力特性モデには、大変形時の柱の耐力低下を 考慮して、最大強度に達した後負勾配を有する武田スリップモテル ${ }^{10}$ （図 8）を用いた（図 19 参照）。図 7 中に復元力特性のスケルトン を破線で示す。

最大強度時の変形 $\delta \mathrm{y}$ は実験結果を参考にして定めた。極脆性柱 では部材角 $0.6 \%(0.2 \%)$ とした。ここで実験結果より大きい部材角 としたのは、この試験体の結果が例外的であり、他の $\mathrm{h}_{0} / \mathrm{D}=2$ の試験 体で得られた最大強度時の変形が部材角 $0.43 \sim 0.66 \%$ でったため である。せん断柱では実験結果と同じ部材角 $1.0 \%$ (0.67\%) とした。 曲げ柱では、部材角 $1.0 \%$ （0.67\%）とした。この試験体では部材角 1.0\%程度で降伏したあとしばらくして、前述の最大強度を迎えた。

$\delta \mathrm{y}$ 以降は、極脆性柱とせん断柱では最大強度後の急激な耐力低 下を考慮して、部材角 $2 \%$ とき耐力が最大強度の $50 \%$ (極脆性柱)、 60\%（せん断柱）に低下するものとした。曲げ柱は部材角 2\%まで最 大強度を保持するものとした。

すへての柱で、実験より得られた軸力保持限界時変形を柱の耐力 がゼロになる変形 $\delta \mathrm{u}$ とした。 3 層建物の 1 3 首、 5 層建物の $3 \sim 5$ 層の $\delta \mathrm{u}$ はこのように決めたが、軸力が大きい場合変形能力が低下 することを考慮して、 5 層建物の 1 ， 2 層の $\delta \mathrm{u}$ はこれらの $90 \% 、 95 \%$ とした。 $\delta \mathrm{u}$ 以降の剛性はほぼゼロを仮定して初期剛性の $1 / 10,000$ とした。

表 2 に、 3 層と 5 層建物における上部 3 層の構造諸元を示す。

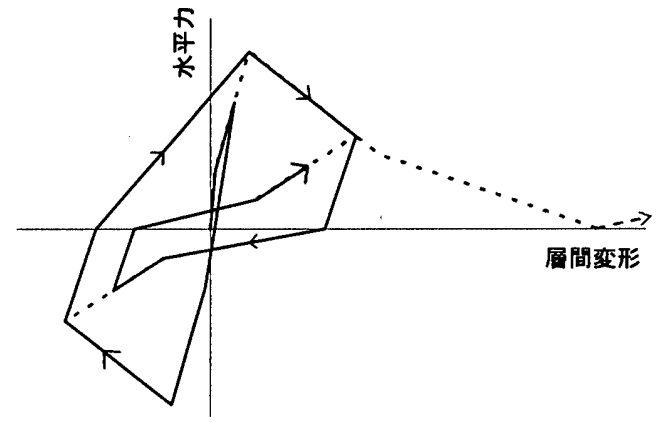

図 8 復元カモデル

表 2 上部 3 層の構造諸元

\begin{tabular}{c|c|c|c|c|c|c}
\hline \multirow{2}{*}{ 部材 } & \multirow{2}{*}{$\begin{array}{c}\text { 内法高さ } \\
(\mathrm{cm})\end{array}$} & \multicolumn{2}{|c|}{$\delta \mathrm{y}(\%)$} & \multicolumn{2}{|c|}{$\delta \mathrm{u}(\%)$} & \multirow{2}{*}{$\mathrm{F}$ 值 } \\
\cline { 3 - 6 } & & 部材角 & 層間変形角 & 部材角 & 層間変形角 & \\
\hline 極臲性柱 & 120 & 0.6 & 0.2 & 7.8 & 2.6 & 0.8 \\
\hline せん断柱 & 240 & 1.0 & 0.67 & 13.4 & 8.9 & 1.0 \\
\hline 曲げ柱 & 240 & 1.0 & 0.67 & 17.9 & 11.9 & 1.1 \\
\hline
\end{tabular}

\section{4 被災度判定}

柱の損傷度は、実験による水平カー变形関係と破壊状況写真を基 に、文献 3)に示された各損傷度の例を参考にして、0〜Vに分けた。 図 7 中に損傷度と変形の関係を示す。極脆性柱とせん断柱では、 0.2 $\delta \mathrm{y}$ までを $0 、 0.5 \delta \mathrm{y}$ までを I 、 $\delta \mathrm{y}$ までをII、部材角 $2 \%$ までを四、 $\delta \mathrm{u}$ までをIVとし、それ以降をVとした。曲け柱では、0.25 $\delta \mathrm{y}$ まで を $0 、 \delta \mathrm{y}$ までを I 、部材角 $2 \%$ までをII 、部材角 $4 \%$ までをIII、 $\delta \mathrm{u}$ までをIVとし、それ以降をVとした。本研究では、軸力保持限界を 超えたあとを損賃度 Vとしたが、これは文献 3)における損倠度 Vの 概念（残存水平耐力と残存銷直耐力がともになし）と対応させたも のである。一方、文献 3)では水平耐力が低化し始める領域を損傷度 IVとしているが、本研究ではそれを損傷度しした。これは、実験 では耐力が低下し始めたあとも相当大きな変形まで軸力を保持でき たことから、最大強度後の領域を細分化する意図によっている。な お、損傷度 I 、II、III、IVの決定にはひび割れ幅も重要となるが、 模型試験体であったこともあり、特別な考慮はしなかった。

被災度レベルは、耐震性能残存率 $\mathrm{R}^{3}$ により判定した。 $\mathrm{R}$ は被災前 の Is 值に対する被災後の Is 值（DIs）の比として求まる。DIsは、柱 の損賃度によって決まる耐震性能低減係数 $\eta$ を柱の強度指標に乗じ、 低減された強度指標を用いて耐震診断を行うことにより算定される。 本研究における $n$ は、文献 3)を参考に各損傷度の境界での值を決め、 その間は直線補間した（図 7 および表 3 参照)。なお、極脆性柱が含 まれるモテル 1、2 について、前述のように被災前の Is 值は極脆性 柱を無視した診断基準(4)式により決まったのであるが、ここでは極 脆性柱の損傷度を考慮するために、 $\mathrm{R}$ を求めるときのみ被災前後の Is 值の計算に極脆性柱が破壊する時点での診断基準(5)式を用いた (この扱いが $\mathrm{R}$ を求めるときだけであり、以後の検討に出てくる Is 值はすべて本来の方法によることを注記しておく)。

R による被災度レベルの区分は文献 3)に従った（表 4）。ただし、 文献 3)において、倒袈は明確に定義されていないため、軸力保持限 界時変形 $\delta \mathrm{u}$ が小さい方の柱が崩壊するときの $\mathrm{R}$ をモデルごとに算

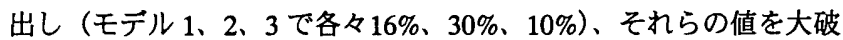
と倒壞の境界とした。

\section{表 3 酎震性能低減係数 $\eta$}

\begin{tabular}{c|c|c}
\hline 損傷度 & 極脆性柱、せん断柱 & 曲げ柱 \\
\hline 0 & 1 & 1 \\
\hline I & $1 \sim 0.95$ & $1 \sim 0.95$ \\
\hline II & $0.95 \sim 0.6$ & $0.95 \sim 0.75$ \\
\hline III & $0.6 \sim 0.3$ & $0.75 \sim 0.5$ \\
\hline IV & $0.3 \sim 0$ & $0.5 \sim 0$ \\
\hline V & 0 & 0 \\
\hline
\end{tabular}

表 4 酎要性能残存率 R(X)による被災度レベルの区分

\begin{tabular}{c|c|c|c}
\hline 被災度 & モデル 1 & モデル 2 & モテル 3 \\
\hline 軽微 & \multicolumn{3}{|c}{$95 \leqq \mathrm{R}$} \\
\hline 小破 & \multicolumn{3}{|c}{$80 \leqq \mathrm{R}<95$} \\
\hline 中破 & \multicolumn{3}{|c}{$60 \leqq \mathrm{R}<80$} \\
\hline 大破 & $16 \leqq \mathrm{R}<60$ & $30 \leqq \mathrm{R}<60$ & $10 \leqq \mathrm{R}<60$ \\
\hline 倒壊 & $\mathrm{R}<16$ & $\mathrm{R}<30$ & $\mathrm{R}<10$ \\
\hline
\end{tabular}




\section{5 地震応答解析}

入力地震動として、1995 年兵庫県南部地震における神戸海洋気象 台 EW（JMA）と大阪カス茸合供給所 N240E（FKI）、1978 年宮城県 沖地震における東北大学 NS（TOH）、1968 年十勝冲地震における八 戸港湾 $\mathrm{EW}(\mathrm{HAC})$ の 4 つを用いた。兵庫県南部地震の地震動は EW 方向のものとしたが、これは、本研究で解析と実被害の対応を比較 する際に対象とした被害調查結果が学校校舎の析行方向に関するも のであり、採光等の理由により妳行が東西方向であるものが多かっ たためである。宮城県沖地震と十勝沖地震については地震動レベル の大きい方を用いた。

解析では、原記録および原記録を耐震設計時によく考慮される最 大速度 $50 \mathrm{~cm} / \mathrm{s}$ に基淮化した地震動を使用した。後者の場合の原記録 に対する比率は、JMA、FKI、TOH、HAC で各々、0.69、0.76、1.20、 1.58 である。図 9 に原記録についての加速度応答スペクトルを示す。 地震応答解析における粘性減衰は、初期剛性比例型で減衰定数を 0.02 とした。なお、実験において測定された水平力には、P- $\Delta$ 効果 による付加水平力が含まれているため、解析において運動方程式に P- $\Delta$ 効果を考慮することは行わなかった。

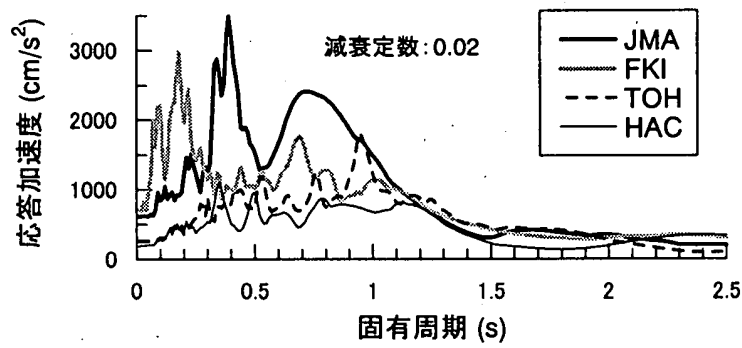

図 9 加速度応答スペクトル（原記録）

\section{3. 解析結果}

\subsection{Is 值-最大層間变形角関係}

Is 值を 0.2 から 1.0 まで 0.05 刻みで変化させて解析を行った。す べての範囲で 3 層建物では 1 層、 5 首建物では 3 層の被害が最も大 きかったので、以下これらの層について論じる。ここで、 5 首建物 で 3 層の被害が最大となる結果は、1 首の被害が最大となる場合が 多いという実現象と異なるが、これは、解析モテルでは上部 3 層の 強度を一定と仮定したために、3 層の Is 值が最小となったことによる。

Is 值と最大層間変形角の関係について、モデル 1 の JMA（最大速 度 $50 \mathrm{~cm} / \mathrm{s}$ ）に対する結果を例として図 10 に示す。図中には、軸力 保持限界時変形 $\delta \mathrm{u}$ が小さい方の柱が崩壊する変形を破線で示して ある。当然ではあるが、Is 值が上がるにしたがい最大層間変形角は 減少している。なお、図中の S (倒壞安全率) については 3.6 節で 述べる。

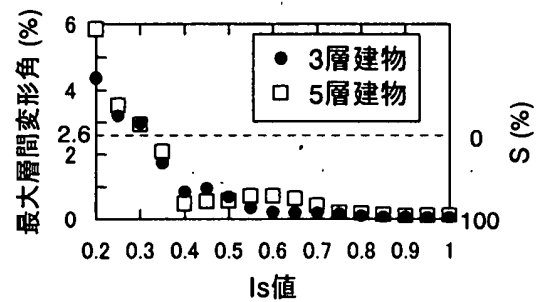

图 10 is 值一最大層間变形角関係（モデル 1、JMA $50 \mathrm{~cm} / \mathrm{s}$ ）

\subsection{Is 值-R 関係}

ここでは、Is 值と文献 3)に示された耐震性能残存率 R の関係につ いて検討する。 $\mathrm{R}$ は最大層間変形角に対してモデル毎にひとつの值 となる。図 11 に層間変形角と $\mathrm{R}$ の関係を示す。この図から、首間 変形角の増加と $\mathrm{R}$ の減少が直線的な関係にはないことがわかる。つ まり、層間変形角が小さい範囲では層間変形角の增加に対する $\mathrm{R} の$ 減少が大きいが、層間変形角が大きくなると $\mathrm{R}$ の減少は小さくなる。 また、図 11 中に、被災度が倒壊となる点（片方の柱が崩壊する点） を示す。仮定により、倒㐭時の層間変形角はモデル 1 と2では同じ で、モデル 3よりかなり小さい。

原記録と最大速度 $50 \mathrm{~cm} / \mathrm{s}$ の地震動に対して、各 Is 值について求 めた最大層間変形角から、図 11 により $\mathrm{R}$ を定めた。図 $12 、 13$ に Is 值-R 関係を示す。 3 首、 5 首建物において、同じ Is 值に対する $\mathrm{R}$ は、 JMA における一部の場合を除いて同程度であり、3 層建物と 5 首建 物の固有周期の違いによる差は小さい。これより、以後の検討では これらをまとめて論じる。

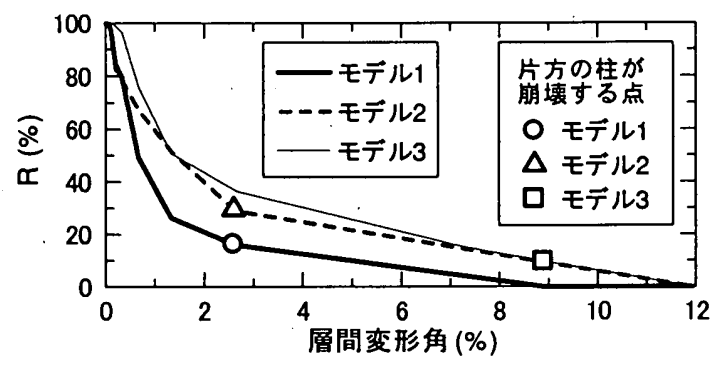

图 11 層間变形角-R 関係

\section{3 原記録の地霞動}

(1) Is=0.6の場合の被災度（実被害との対応）

診断基準における構造耐震判定指標 Iso は 2 次診断で 0.6 とされ、 Is IIso を満足する建物は「安全」とされる。この判断の基となった のが、Is 值が 0.6 以上の建物には、「宮城県冲地震と十勝冲地震では 中破以上の被災度となったものがなく、また、兵庫県南部地震では 大破以上の被災度となったものがなかった」という一般認識である。 そこで、本解析における Is=0.6 の場合の被災度がどの程度であるか を検討する。各モデルについて、Is $=0.6$ の場合の耐震性能残存率 $\mathrm{R}$ （3 首、 5 層建物のうち值の小さい方）を図 14 に示す。

JMA に対してはすべてのモデルで大破、FKI に対してはモデル 1 と 2 で中破、モデル 3 で小破以下、TOH と HACに対してはすべて のモテルで小破以下であった。つまり、TOH と HACに対しては宮 城県沖地震と十勝沖地震における認識と一致した。FKIに対しても 兵庫県南部地震における認識と一致したが、JMA のみそれより厳し い結果となった。この理由としては、本研究で設けた種々の仮定の ほか、学校建築の梁間方向には耐震壁が設けられていることが多く それが柱の損傷を㧕える働きをするが、本研究ではそれを考慮しな かったことが考えられる。

\section{(2) 倒壊を免れるために必要な Is 值}

地震時に建物が倒壊に至ると人命に対する危険が非常に大きいた め、どの程度の Is 值があれば倒壊しないかを把握することが重要で ある。図 12 中に倒壊を免れるために必要な Is 值を破線で示し、図 15 にそれらの值をまとめて示す。 

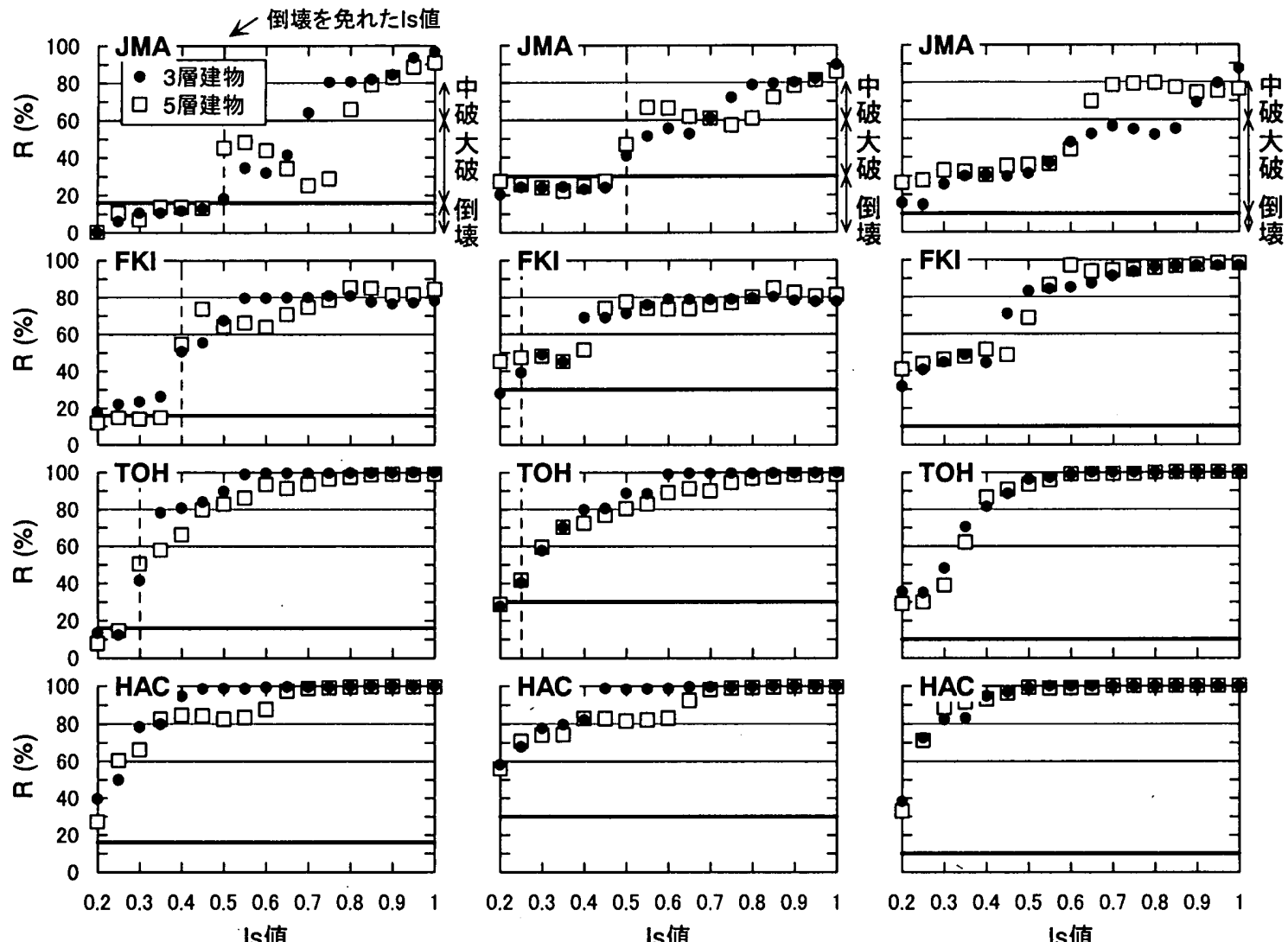

$\begin{array}{lllllllll}0.2 & 0.3 & 0.4 & 0.5 & 0.6 & 0.7 & 0.8 & 0.9 & 1\end{array}$ Is 值

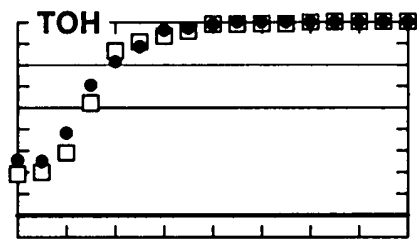

(a) モデル 1

(b) モデル 2

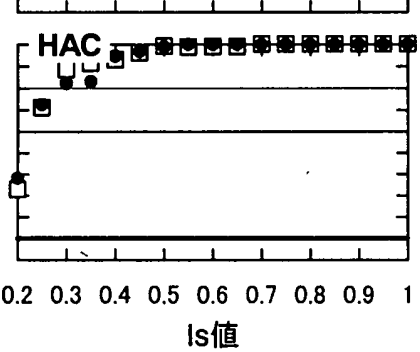

(c) モデル 3

図 12 Is 值 $-\mathrm{R}$ 関係（原記録）
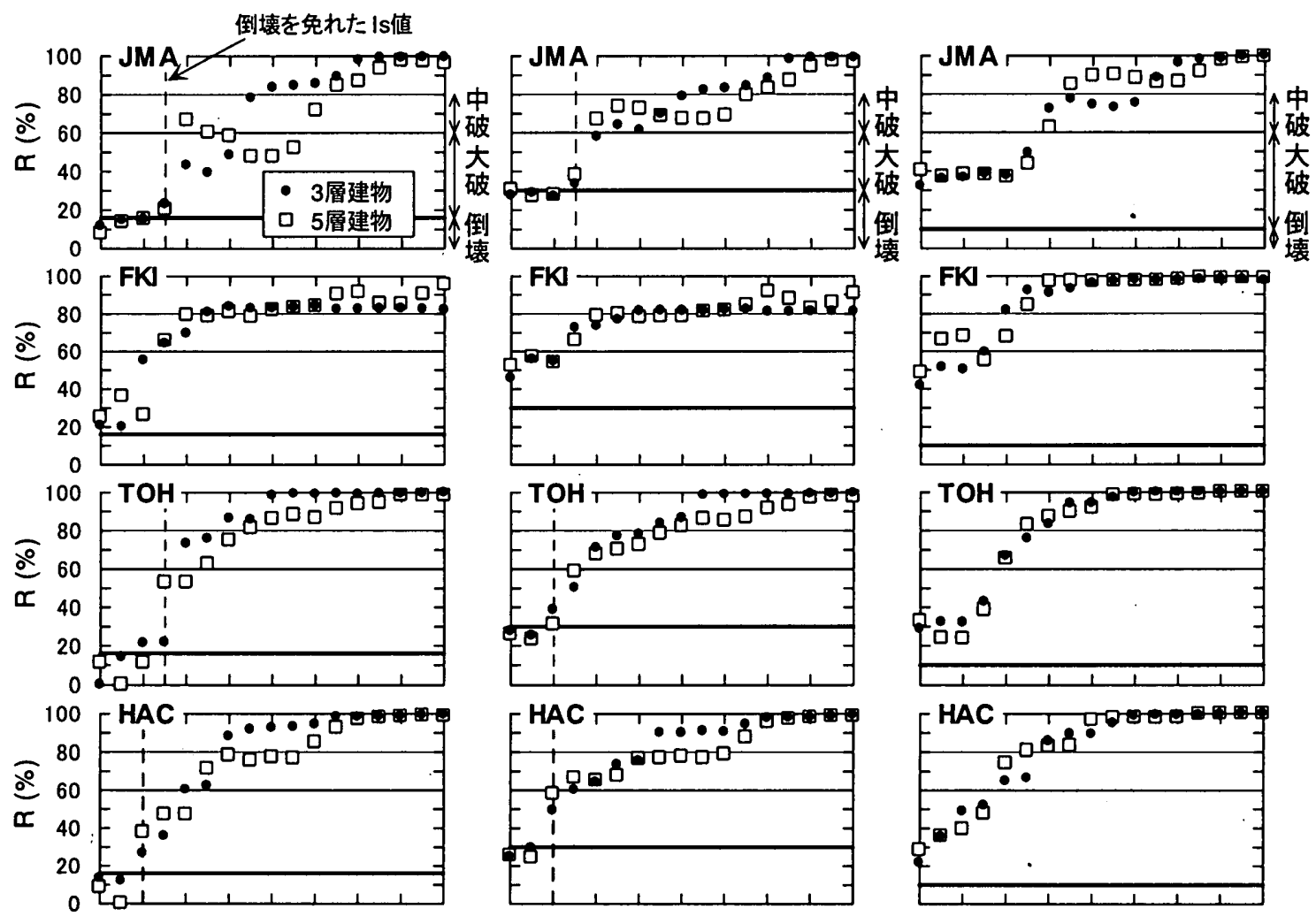

$\begin{array}{lllllllll}0.2 & 0.3 & 0.4 & 0.5 & 0.6 & 0.7 & 0.8 & 0.9 & 1\end{array}$ Is 值

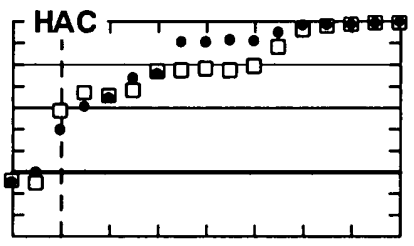

$\begin{array}{lllllllll}0.2 & 0.3 & 0.4 & 0.5 & 0.6 & 0.7 & 0.8 & 0.9 & 1\end{array}$ Is 值
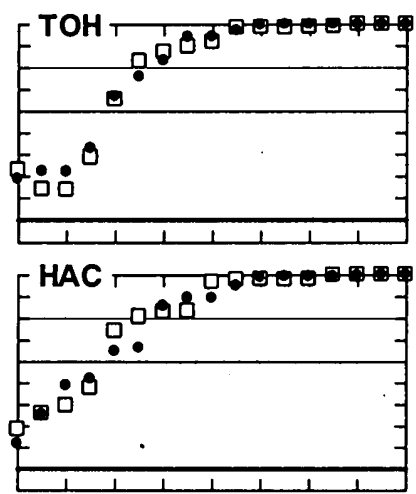

$\begin{array}{lllllllll}0.2 & 0.3 & 0.4 & 0.5 & 0.6 & 0.7 & 0.8 & 0.9 & 1\end{array}$

s 值

(a) モテル 1

(b) モデル 2

(c) モデル 3

图 13 Is 值-R 関係（最大速度 : $50 \mathrm{~cm} / \mathrm{s}$ ) 
JMA に対してはモデル 1 と2で Is=0.5、FKI に対してはモデル 1 で Is=0.4、モデル 2 で Is=0.25、TOH に対してはモデル 1 で Is=0.3、モ デル 2 で Is=0.25 あれば倒壊を免れた。HAC を含むその他のケース では Is=0.2でも倒壊しなかった。これより、地震動レベルが大きい 兵庫県南部地震に対しても、Is 值が 0.5 あれば倒壊を免れることが わかる。

\section{4 最大速度 $50 \mathrm{~cm} / \mathrm{s}$ の地震動}

\section{(1) Is $=0.6$ の場合の被災度}

各モテルについて、Is $=0.6$ の場合の耐震性能残存率 $\mathrm{R}$ を図 16 に示 す。FKIに対してはモデル 2 で中破、モデル 1 と 3 で小破以下、HAC に対してはモデル 1 と 2 で中破、モデル 3 で小破以下、TOHに対し てはすべてのモデルで小破以下であった。ここで、FKI と HAC で中 破となった場合の R は 80 に近く、小破に近いといってよいであろ う。これより、Is=0.6 は、FKI、TOH、HAC では、最大速度 $50 \mathrm{~cm} / \mathrm{s}$ の地震動に対して被害が概ね小破以下に収まる值であるといえる。 一方、JMAに対してはモデル 1 で大破、モデル 2 と 3 で中破であっ た。ただし、大破となったモテル 1 の場合 ( 5 層建物)でも、 $\mathrm{R}=48 \%$ 、

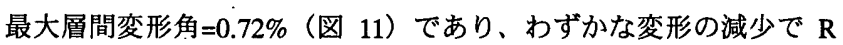
が大きく增加する領域に入っていることに注意が必要である。

（2）倒壊を免れるために必要な Is 値

図 13 中に倒增を免れるために必要な Is 值を破線で示し、図 17 に それらの值をまとめて示す。JMAに対してはモデ 1 と 2 で Is=0.35、 TOH に対してはモデル 1 で Is=0.35、モデル 2 で Is $=0.3 、 \mathrm{HAC}$ に対 してはモデル 1 と 2 で $\mathrm{Is}=0.3$ あれば倒榬を免れた。FKI を含むその 他のケースでは Is=0.2 でも倒壞しなかった。これより、耐震設計で よく考慮される最大速度 $50 \mathrm{~cm} / \mathrm{s}$ の地震動に対して倒壊を免れるた めには、極脆性柱を含む建物では 0.35 以上の Is 值が必要であること がわかる。言い換えると、極脆性柱を含む既存建物で Is 值が 0.35 に満たない建物に対しては、早急な対策が必要であるといえる。

\section{5 各モデルの比較}

ここでは、各モデルについて解析結果を比較し、柱種別の違いに よる影響を検討する。

図 14、16 によると、Is=0.6 の場合の耐震性能残存率 R は、JMA の場合を除いて、概ねモデル 1 と 2 では同程度、モデル 3 ではそれ らより大きい。これより、柱種別の違いにより、同じ Is 值に対して も被災度は異なり、極脆性柱が存在する場合にはそれがない場合よ゙ り被災度が大きくなる傾向にあるといえる。

また、図 15、17 よると、倒壊を免れるために必要な Is 值は、モ デル 1 とモデル 2 では同程度であり、モデル 3 では Is $=0.2$ でも倒壊 しない。これより、倒壊を防ぐために必要な Is 值に関しても、極脆 性柱が存在する場合にはそれがない場合より不利であるといえる。 ただし、本研究における倒塄の定義より、モデル $1 、 2$ ではモデ 3 よりかなり小さな層間変形角で倒壊とみなされることに注意が必要 である(図 11 参照)。

\section{6 倒壊安全率-R 関係}

耐震性能残存率 $\mathrm{R}$ の算出過程には、柱の耐震性能低減係数 $\eta$ など、 いくつかの仮定的要素が含まれているため、最大層間変形角との関
係が単純ではない（図 11 参照)。そこで、最大層間変形角との関係 がより直接的な指標として、倒壊時首間変形角に対する倒壊時首間 変形角と最大層間変形角の差の比として求められる倒壊安全率 $\mathrm{S}$ （Collapse Safety Index）を考える。ここで、最大首間変形角が倒堍 時層間変形角より大きいときは $\mathrm{S}=0$ とする。 $\mathrm{S}$ は倒滾に至るまでの 層間変形角のマージンを表す値である。S と Rの関係を図 18 に示す。 また、図 10 中に S の軸を記入する。 $\mathrm{S}$ と最大層間変形角は直線的な 関係にあるが、 $\mathrm{R}$ と最大層間変形角がそうでないため(図 11 参照)、 $\mathrm{S}$ と $\mathrm{R}$ も直線的な関係にはない。

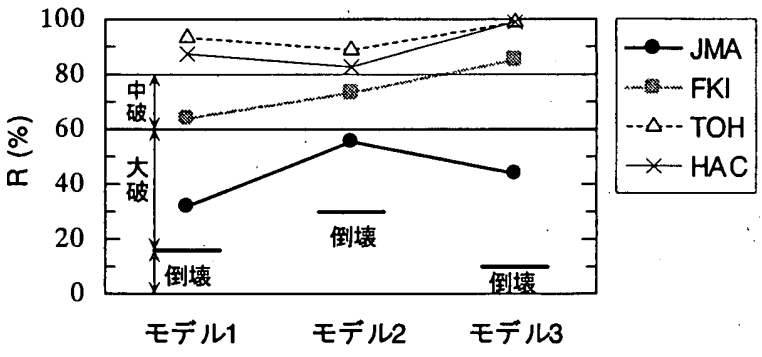

図 14 I $\mathrm{s}=0.6$ の場合の $R$ (原記録)

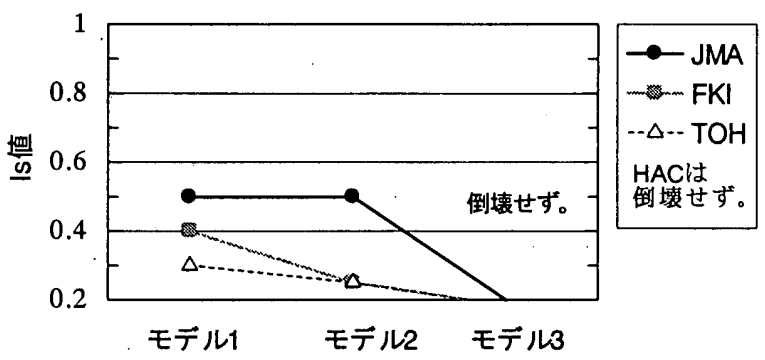

図 15 倒壊を免れるために必要な Is 值（原記録）

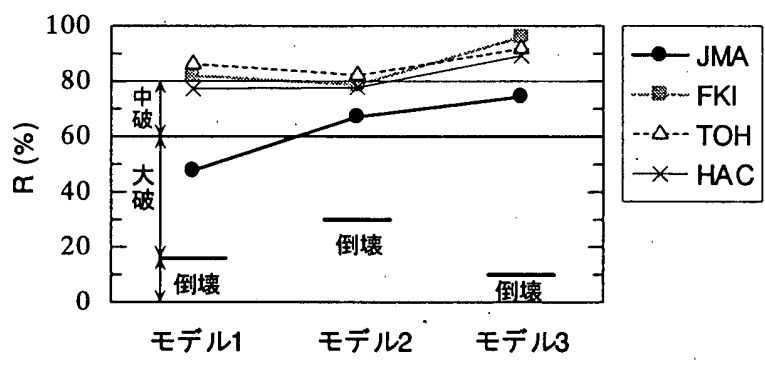

図 16 is $=0.6$ の場合の $R$ （最大速度 : $50 \mathrm{~cm} / \mathrm{s}$ ）

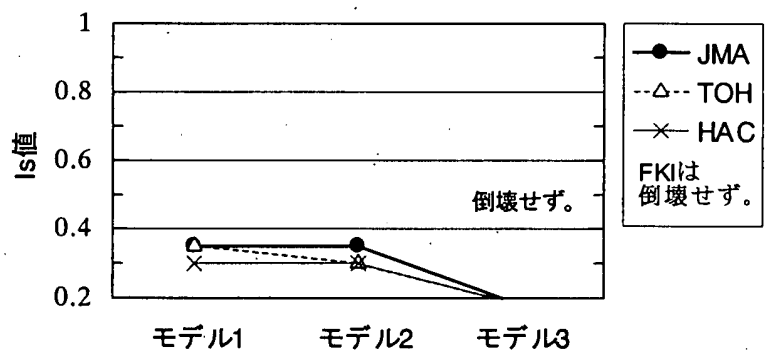

図 17 倒壊を免れるために必要な $1 \mathrm{~s}$ 值（最大速度 : $50 \mathrm{~cm} / \mathrm{s}$ ） 


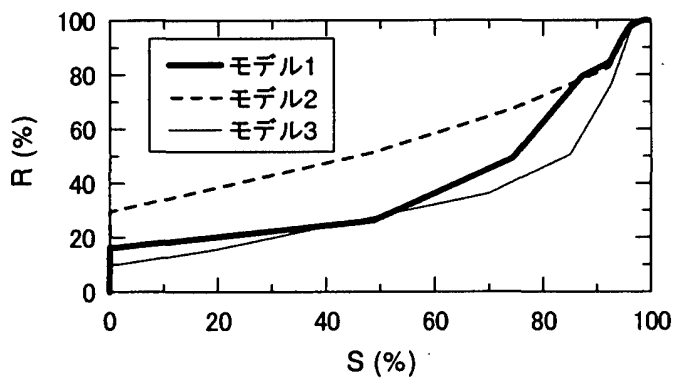

图 18 S-R 関係

\section{7 is 值と被災状況の関係}

建物モテルと地震動に応じて図 12、13 のように Is 值に対する耐 震性能残存率 $\mathrm{R}$ が与えられると、 $\mathrm{R}$ から図 11 、図 18 により最大層 間変形角と倒壊安全率 $\mathrm{S}$ が求められる。さらに、写真 1 より最大層 間変形角に対応する柱の損傷度がわかる。

Is 值と被害状況の関係を、JMA $50 \mathrm{~cm} / \mathrm{s}$ に対する 3 層建物・モデル 1 を例として検討する。Is=0.3 および Is=0.55 の場合の結果を 1 層の 水平力ー層間変形角関倸とともに図 19 に示す。

Is $=0.3$ 時の耐震性能残存率 R は $15 \%$ （被炎度は倒壞）、倒壞安全 率 S はゼロであり、最大層間変形角は-3\%である。極脆性柱は崩壊 し、せん断柱にも多数のひび割れが入っている。一方、Is $=0.55$ 時の $\mathrm{R}$ は 78\% (被災度は中破)、S は 87\%であり、最大層間変形角は-0.35\% である。極脆性柱には大きなせん断ひび割れが入っているが、せん 断柱はほとんど被害を受けていない。なお、このときの $\mathrm{S}=87 \%$ は、 倒壞に至るまでにあと倒壊時首間変形角の $87 \%$ 変形できることを示 している。

このように、建物階数、柱種別、Is 值および地震動が与えられた 場合、本研究で示した方法により地震時に受ける被災度と被災の様 子を推定することができる。
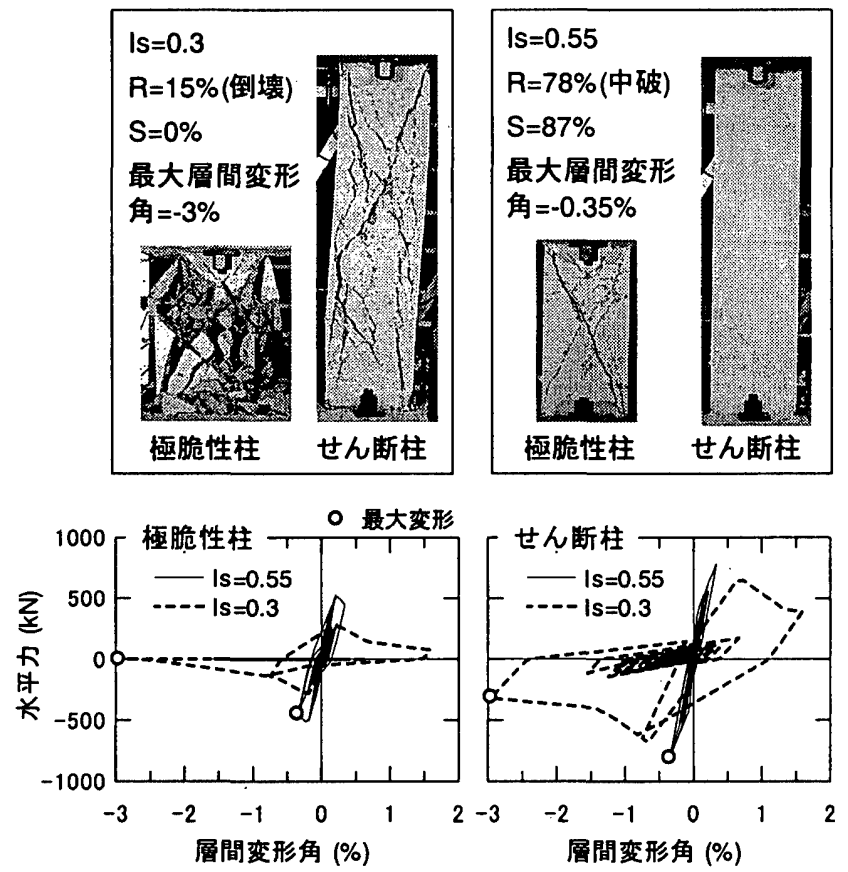

图 19 被災状況と水平力-層間变形角関係

(3 属建物、モデル 1、JMA $50 \mathrm{~cm} / \mathrm{s})$

\section{4. まとめ}

地震動原記録および最大速度 $50 \mathrm{~cm} / \mathrm{s}$ の地震動レベルを設定して 旧基準 RC 建物の Is 值と被災度の関係を調べた。ごく限られた範囲 での検討であるが、得られた知見をまとめると、以下のようになる。

1）建物階数、柱種別、Is 值および地震動が与えられた場合、本研究 で示した方法により地震時に受ける被災度と被災の様子を推定 することができる。

2) 原記録の地震動に対する Is=0.6の建物の被災度は、TOH と HAC では小破以下となり実被害と一致した。一方、JMA では大破と なり、実被害より大きな被災度となった。後者の理由のひとつと して、直交壁の影響を解析では無視した点が考えられる。

3）設計時によく考慮される最大速度 $50 \mathrm{~cm} / \mathrm{s}$ の地震動に対して倒壊 を免れるためには、極脆性柱を含む場合には Is 值が 0.35 必要で あった。極脆性柱を含む既存建物で Is 值が 0.35 に満たないもの に対しては、早急な対策が必要であるといえる。

4) 極脆性柱を含む建物は、それを含まない建物に比べて、同じ Is 值に対する被災度が大きかった。

5） 3 首建物と 5 首建物を比較すると、同じ Is 值に対する被災度は同 程度であり、固有周期の影響は見られなかった。

\section{参考文献}

1）日本建築防災協会 : 既存鉄筋コンクリート造建物の耐震診断基準・同 解説、2001 年度改訂版、2001.10

2) 日本建策防災協会 : 震災建築物等の被災度判定基準および復昍技術指 針（鉄筋コンクリート造編）、1991

3）日本建築防災協会: 震災建築物の被災度区分判定基準および復旧技術 指針、2001

4）岡田恒男、壁谷澤寿海ほか : 鉄筋コンクリート造学校校舎の耐震診断 指標値と被災度、第 10 回日本地震工学シンポジウム、Vol.1、pp.177-182、 1998.11

5) 李康碩、中埜良昭、涱澤文俊、岡田恒男 : 1995 年兵庫県南部地震に より被災した建物の耐震性能と被災度に関する研究、構造工学論文集、 Vol.42B、pp.9-14、1996.3

6) 中村孝也、芳村 学、大和征良 : せん断破壊型鉄筋コンクリート短柱 の軸力保持限界に関する研究、日本建築学会構造系論文集、第 561 号、pp.193-199、2002.11

7）高稻宜和、芳村 学、中村孝也 : 鉄筋コンクリート柱の崩壊変形に関 する研究、日本建築学会構造系論文集、第 573 号、pp.153-160、2003.11

8) 田村正男、田中淳夫 : 耐震診断における既存 RC 造建物の耐震性能評 価に関する統計的研究、構造工学論文集、Vol.45B、pp.297-304、1999.3

9）八木克己、中村孝也、芳村 学: 旧基準 $\mathrm{RC}$ 建物の補強後の地震応答、 第 11 回日本地震工学シンポジウム論文集、pp.1585-1588、2002.11 10)中村孝也、芳村 学 : 兵庫県南部地震において中間層崩壊した鉄筋コ ンクリート系建物の地震応答、日本建築学会構造系論文集、第 556 号、pp.123-130、2002.6 